\title{
A STUDY OF AESTHETIC VALUE IN THE INTERIOR SPACE YOGYAKARTA PRESIDENTIAL PALACE AS THE DEVELOPMENT OF A NEW INTERIOR SPACE CONCEPT
}

\author{
Ika Yuni Purnama ${ }^{1,}$, Tjetjep Rohendi Rohidi ${ }^{1}$, Setiawan Sabana ${ }^{2}$, Triyanto $^{1}$, Nur Fajrie ${ }^{3}$ \\ Universitas Negeri Semarang, Indonesia ${ }^{1}$ \\ Institut Teknologi Bandung, Indonesia ${ }^{2}$ \\ Universitas Muria Kudus, Indonesia ${ }^{3}$ \\ E-mail: ikayuni@ senirupaikj.ac.id
}

\begin{abstract}
This study examines the community can still enjoy the importance of interior in the Yogyakarta Presidential Palace as a form of cultural heritage. About that, aesthetic value and interior space concept will be arranged in an example kind of new in visual forms. The interior space of the Yogyakarta Presidential Palace concept was a development from the interior space concept during the era of Sukarno. This research is based on the aesthetic and historical approach that stressed on the artistic aspects and design that are associated with aesthetic appeal. The study uses a qualitative research method with an interdisciplinary approach that includes historical, social, cultural, and aesthetic approaches by not leaving descriptive aspects and critical analysis of reading sources and field surveys. It is inductive qualitative research because the inductive process is more able to find multiple realities as contained in the data. The analysis was done using observations of form and function, including the meaning of space composition, which was arranged to ${ }^{1}$ produce a proportionate composition with the art collection object. This research is expected to be a basis for the interior aesthetic of the Yogyakarta Presidential Palace and to contribute to designers in the fields of architecture, fine arts, and especially the interior design. Also, this research is expected to be a source of reference for the Presidential Palace of the Republic of Indonesia concerning the aesthetics interior. The aesthetic interior of the new Yogyakarta Presidential Palace can be sharpened by presenting the power of essential values in a particular room with special collections and backgrounds.
\end{abstract}

Keywords:

Aesthetic, interior, Yogyakarta, Presidential Palace, design concept

Article Received: 18 October 2020, Revised: 3 November 2020, Accepted: 24 December 2020

\section{Introduction}

The Presidential Palace of the Republic of Indonesia Yogyakarta is one of the buildings with architecture and interiors that holds many collections, which are solid materials that are inseparable from parts of the interior layout concept and as elements of the interior. Art collections are part of the interior layout. The Presidential Palace is essential to introduce space and the existence of space for the presentation of art objects as part of the interior of the Presidential Palace of the Republic of Indonesia Yogyakarta. The Yogyakarta Presidential Palace, which has history and aesthetics, cannot be ignored. However, they must be preserved through the development of design and art that can be used as standard feasibility as a museum. This is related to the appeal of the UNESCO World Organization (United Nations for Education, Science, and Culture) about the Constitution with No. 11. 2010 from the UNESCO conference, in material cultural heritage in the form of cultural heritage forms, cultural heritage buildings, and cultural heritage sites or in the air that required religion, education, religion, and cultural processes.

The Yogyakarta Presidential Palace has unique characteristics because it has an art collection and architectural interiors that have a significant history and culture for Indonesia. The Yogyakarta Presidential Palace can be considered as 
knowledge and education to make the Indonesian people know the historical and cultural heritage that must be preserved. Maintaining historical and cultural heritage requires several developments in architecture, interiors, collection arrangements presentation of collection objects, and visual information. Another consideration is the selection of a collection of historical works of art to support art learning for the Indonesian people.

Previous studies have debated Indonesia's president, Sukarno started the concept of the Presidential Palace of the Republic of Indonesia's collection of art objects. This article will focus on the critical issues of this collection's curation using qualitative research methods, in the hopes of revealing various curatorial issues. Over 70 years, the Presidential Palace's collection has undergone various forms of curation, including acquisition, documentation, preservation, and exhibition (Susanto, Simatupang, Haryono, 2018). Yogyakarta Presidential Palace is currently a complex that contains an extraordinary collection of historic buildings from several eras, and it has a collection of objects that originate from, represent, and relate to evidence of human material and its environment that have national and international value. Yogyakarta Presidential Palace also presents a collection in a large open area consisting of building models and statues as a complementary collection in the parks around the Palace.

The space concept is an essential problem in interior design. That is why the problem of space became an essential consideration for this research. The inner or interior space in the Yogyakarta Presidential Palace is a room that has essential and historical value. Examples of these spaces are the Garuda room, the Sudirman room, and the Diponegoro room. Thus, at the Yogyakarta Presidential Palace, the concept of space unification and the governance of the art collection are the result of the unity of internationalism with modern cultural and technological patterns with values, nuances of history, and culture of Indonesia. Interior design is the planning, layout, and design of interior space buildings. This physical arrangement fulfills the basic protection needs, regulates space, and influences the form of activities, maintains aspirations, and expresses ideas include actions, views, moods, and personality. The purpose of interior design is a functional improvement, aesthetic enrichment, and psychological improvement in interior spaces (D.K. Ching, 2002:46).

\section{Method}

The research method used is qualitative research with a multidisciplinary approach covering historical, social, cultural, and aesthetic approaches by not leaving the descriptive aspect and critical analysis of reading sources and field surveys. Inductive qualitative research implemented because the inductive process is more able to find multiple realities as contained in the data. Data collected was in the form of written or oral words, pictures, and not numbers (Lexy, J.Moleong, 2006:9).

Interior and artistic designs are the basis of cultural-based development in interior design. Constructive discussion is a broad discussion. Several archival documents relating to collections and examining the work of collection curators, from inventory to opening collections to the public. Over the past 70 years, the Presidential Palace collection has undergone various forms of curation, including acquisitions, documentation, preservation, and exhibitions. This research concludes that the role of the curator is significant and causes the collection to be retained and more valuable. Such is the case about the collection of art objects in the Yogyakarta Presidential Palace to give meaning to space so that it is a unique museum that deals with paintings in the palace collection ( Susanto, M, Simatupang, GR.Lono L, and Haryono, T, 2018).

Collection management by presenting paintings in museums is more direct to permanent/permanent exhibitions because they are conceptual in a mature manner. Whereas in the Palace complex, which is outside the museum, the presentation leads to a temporary/incidental exhibition, because it can 
change at any time, for rolling/replacement. In connection with the writing of this dissertation, the data contained in this journal article is very helpful in collecting the collection of paintings of the Yogyakarta Presidential Palace (Annam, K,2019). There are three essential findings in this study, as follows: (1) the importance of interior spaces in Yogyakarta Presidential Palace (2) the importance of art collection at Yogyakarta Presidential Palace, and (3) interior development by visitors.

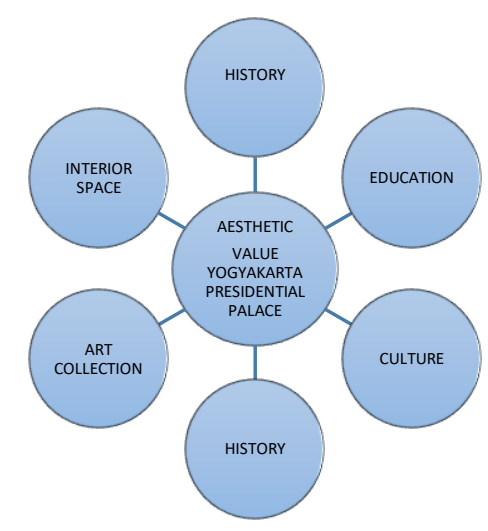

Figure 1. Research Concept

\section{Result and Discussion}

Aesthetics in technical terms is the knowledge of beauty and loveliness in general. The word aesthetic came from the Greek term "Aesthesis," which means feeling or sensitivity. This is due to the close relationship between beauty and taste, or in German, it is known as "Geschmack." However, currently, the term is interpreted as the philosophy of art. Aesthetics is similar to the logic that creates "single trifecta" in the normative knowledge of philosophy (Wadjiz,1980: 5)

Reaffirmation of the aesthetics and space concepts that are implemented in the Yogyakarta Presidential Palace is intended for future usefulness. The formulation and value concepts can be coordinated with current space until it can benefit a broader community. With the understanding of knowledge, the vision regarding identity in modern interior design (with Presidential Palace soul by having art collection object) will be better. The knowledge can also contribute to the development of interior design concepts with the interior concept of the New Presidential Palace.

These values have content, and content is the meaning through forms. Interior space is a functional unity of aesthetic form, namely physical aspects such as style, size, and shape, as well as aspects of meaning taken from history and interpretation of collection objects that can connect between the past and the present. Culture in the interior context of the Yogyakarta Presidential Palace includes spatial planning, supporting elements of floors, walls, ceilings, and aesthetic elements as well as the artistic value of the collections inside which will relate to how space can be utilized, responded to, and appreciated. Interior Science, as part of applied art, combines aspects of beauty/aesthetics, and the humans strive to give meaning to their life span by making interpretations that are by their beliefs. This belief is in the design (architectural-interior context), in the form of thought concepts, which visual language into forms (Widagdo,2006: 11).

The interior spaces of the Yogyakarta Presidential Palace are an interior design that has a universal scope influenced by environmental, cultural, and technological factors. On the other hand, as a cultural value, the Yogyakarta Presidential Palace develops by the development of community needs and humanitarian goals. The architectural process is a human effort to express and to perfect ourselves more humanly. Psychic space can make a perception in humans to respond to the conditions of the space occupied. Perception is the process of obtaining or receiving information from the environment. Perception is not just sensing, said to be the interpretation of experience. Interior design must contain precise meanings through the perceptions that expressed-the importance of art collection at Yogyakarta Presidential Palace. The space element must be able to support the function of space so that it is easy to recognize what activities occur in the space. Ordering of these various activities is one way to show the perception of space. A clear spatial structure will help to provide psychological and symbolic support so that 
it can be a source of emotional/psychological comfort and as a basis for self-actualization (Suptandar, 1999: 72).

Yogyakarta Presidential Palace has spaces with variety and flexibility over its rooms and has a collection of art objects. Collections that have artistic value are interior elements that can create spaces with more opulent art. The primary purpose of the interior is how to create the atmosphere and function space of a building, which can meet the physical and emotional needs of users. Physically, elements and systems in interior analysis from architecture, including forms (floor plans, visible buildings, etc.), organization of space, circulation, proportions, and so on. Whereas in interior spaces, furnishings and decorations provide optimization of activities and expressions of beauty. The aesthetic position in a design (were), not starting through definitive statements (what). This does not mean there are no aesthetic theories that are not used.

On the contrary, these theories underlie the practice of design, namely the aesthetic concept. In the interior design of the Yogyakarta Presidential Palace, several fields of science are interrelated and mutually supportive such as History, Architecture, Graphics, Lighting, and Art governance. Unfortunately, the interior Yogyakarta Presidential Palace still has not obtained a very optimal value as a heritage object that has arts learning on its interior.

\section{Yogyakarta Presidential Palace}

The Yogyakarta Presidential Palace is a witness to the history of the Indonesian people. Starting from the construction, until everything that happens in it is very important and determines the future of the Indonesian people. In the architectural and interior layout of the Yogyakarta Presidential Palace, we can see that there are the existence and development of buildings in Indonesia by the Dutch, which is characterized by the Dutch East Indies architectural style. In Indonesia. From several sources of literature on the development of buildings of Dutch influence, there is an explanation of efforts to combine Dutch architectural styles with local Indonesian architecture, which began in the 18th century. The first attempt was made through the houses of villages in the Dutch East Indies in the 18th and 19th centuries. In the academic world, this style is known as the Indo-European Style (IndoEuropean), or the Indian Style sometimes also called the Old Indian Style to distinguish it from the new style. The term Indonesian has the meaning of acculturation, which combines elements of local traditional architecture and European style.

Yogyakarta Presidential Palace since its establishment has a paradigm as an institution or building to store, preserve, care, and exhibit tangible cultural heritage. In Indonesia, the museum is identical to government-owned institutions; it tends to be located in the middle of the city by occupying the ancient buildings of cultural heritage. Among its landmarks are;(1) It was managed by a state institution, not Private Corporation, (2) The collections are arranged based on a theme rather than an encyclopedic collection that relies on massive quantities, (3)There has been more meaningful cultural heritage (collective memory) or events that are not objects (intangible heritage) and not always rely on tangible heritage of the material (tangible heritage) or, in other words, not object-oriented but informationoriented, (4) Not all collections consist of artifacts and objects of memorabilia. However, some collections consist of the ambiance of contemporary material culture, (5) It uses labels or captions to describe collections on display and rely on tour guides, making them more interactive because they are accessible visually and audibly, (6) It has been museum on movement and monument collections. 7) It is no longer just museum (where studying muse), but it is changed into a museum (theme park) by combining elements of education and entertainment or learning and leisure (Ardhiati, Yuke:2017)

The Yogyakarta Presidential Palace includes buildings of interior architecture, aesthetics, and functions for art collections that present historical 
functions. The art collection of the Yogyakarta Presidential Palace has historical value, and the current meaning of interior architecture ": Art, History, and Aesthetics" is significant. In conclusion, the interior architecture of the Yogyakarta Presidential Palace is significant and very important to enhance the aesthetics that can become information on cultural history with a form of development consisting of art collections, buildings, space, shapes, color, lighting and displays, and the selection of art collection objects. Some researchers are interested in the presidential Palace's art collection for museum development. Previous studies in the sense that they both emphasize aesthetic specificity even though they do not follow their outdated views of interior aesthetic experiences as information for the history of the nation.

Historic interior architecture is a means for classical education, can also build awareness of people's nationalism, and encourage the development of public education. The room design in the future can continue to grow by the development of science. The Modern Museum theory says that museums are the dominant "cultural landscape" in reconstructing the past for the present also adds the theory of new museums is about decolonization, giving them control of their represented cultural heritage own. It is about a real cross-cultural exchange. It is not monolithic; it covers many points of view. Culture is not static or frozen but continues to maintain its identity by creating new objects, each with its personality.

\section{Interior Spaces of the Yogyakarta Presidential Palace}

Architecture creates space, while interior design organizes, fills, complements and strengthens the functional arrangement and the realization of its image, sense, ambiance, and space theme, by the characteristics of space users, motion and activities that occur in. The primary purpose of the interior is how to create the atmosphere and function space of a building, which can meet the physical and emotional needs of users. Physically, elements and systems in the internal analysis of architecture, including forms (floor plans, visible buildings, etc.), money organizations, circulation, proportions, and so forth. Whereas in interior spaces, furnishings and decoration provide optimization of activities and expressions of beauty room is located at the front of the center. Yogyakarta Presidential Palace. The Great Building complex has a historical space; here are three examples of spaces that have a historical, as follows: (Garuda Room, Sudirman Room, Diponegoro Room). Interior space is a functional unity of aesthetic form, namely physical aspects such as style, size, and shape, as well as aspects of meaning taken from history and interpretation of collection objects that can connect between the past and the present. Beautiful interior spaces at the Yogyakarta Presidential Palace include spatial planning, supporting elements of floors, walls, ceilings, and aesthetic elements as well as the artistic value of the collections inside, which will relate to how space can be utilized, responded to, and appreciated.

\section{Garuda Room}

Garuda Room is a large room as a formal room that serves to receive state guests. Located right in the middle of the main building, the seven-meter-high room with three sets of terraced chandelier lamps, four old mirrors hanging, and rugs spread out in the middle of the room reinforces the official impression of this room. This room is also used for official events such as the inauguration of the DIY governor. The main room is located at the front of the center. On the walls of the room hung paintings of national heroes such as Pangeran Diponegoro, R.A. Kartini, Doctor Wahidin Soedirohusodo, and Tengku Cik Di Tiro.

During the period of President Susilo Bambang Yudhoyono, the paintings were replaced with photographs of the presidents. The place was also the place of Sjahrir's cabinet, Amir Sjarifuddin's cabinet, Hatta's cabinet, the formation of the United Republic of Indonesia (RIS) to the inauguration of Sri Sultan Hamengkubuwono $X$ and 
Sri Paduka Paku Alam IX as Governor and Deputy Governor of DIY by President Susilo Bambang Yudhoyono in October 2012 The attic is seven meters high. Hanging, there are four sets of multilevel candelabra lights, and old mirrors hanging from the wall grooves. According to the book "Presidential Palace of Indonesia" published by the Indonesian State Secretariat (1995) compiled by Joop Ave, in that place the accompaniment of Sultan Sepuh (Hamengkubuwono II) drew the assistants of the British Governor-General Sir Stamford Raffles because they kicked the pedestal Dampar Kencana (seat bench) from gold) Sultan. When visiting Raffles, the Sultan's accompanist brought a dampar kencana along with the base, which was deliberately made so that the Sultan was taller than Raffles when they sat side by side. This was not approved by Raffles' aide, who considered his superior to be superior to the Sultan.

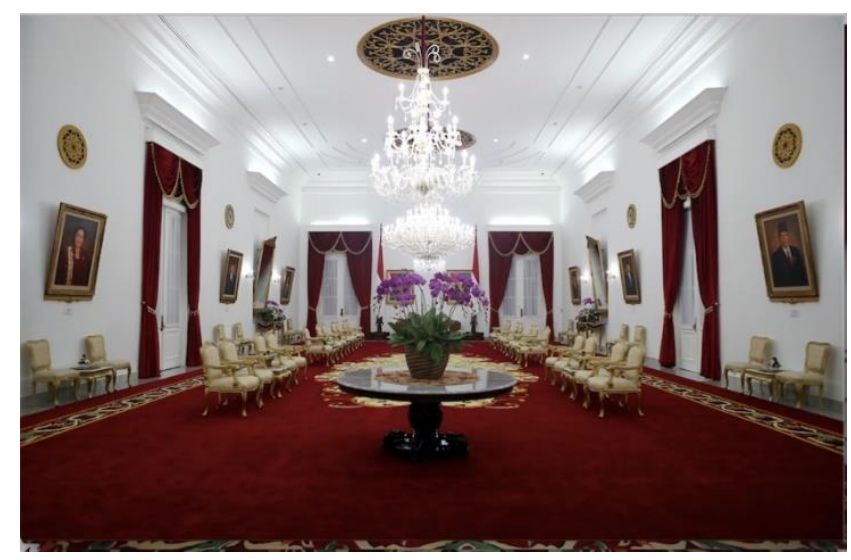

Figure 2. Garuda room of Yogyakarta

Presidential Palace.( Purnama, 2019)

\section{Sudirman Room}

Sudirman Room, located on the left outside Garuda Room, this room is on the south side and faces north. In this room, there is a bust of Commander Soedirman of bronze and several paintings. The Sudirman Room is now used for a living room and private talks and to commemorate the struggle of Commander Soedirman in leading the guerrillas against the Dutch. It was in this room that former Commander in Chief Soedirman appealed to President Soekarno to leave the city to lead a guerrilla war against the Dutch. Sudirman Room is now used for the living room and private talks.

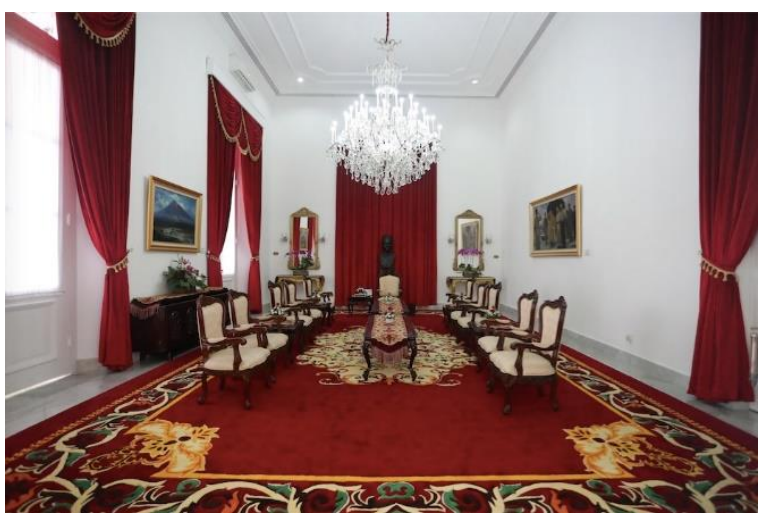

Figure 3. Sudirman room of Yogyakarta Presidential Palace.(Purnama 2019)

\section{Diponegoro Room}

Diponegoro Room, located opposite the Sudirman Room (on the north side of Gedung Agung facing south). Named as a form of appreciation for the services of Prince Diponegoro. In this room, there is a picture of Prince Diponegoro, a replica of a painting by Basuki Abdullah in the Merdeka Palace in Jakarta. Diponegoro Room is a room that is used for seating guests at certain public events. Located to the left of the Garuda room, its naming is a form of appreciation for the services of Prince Diponegoro.

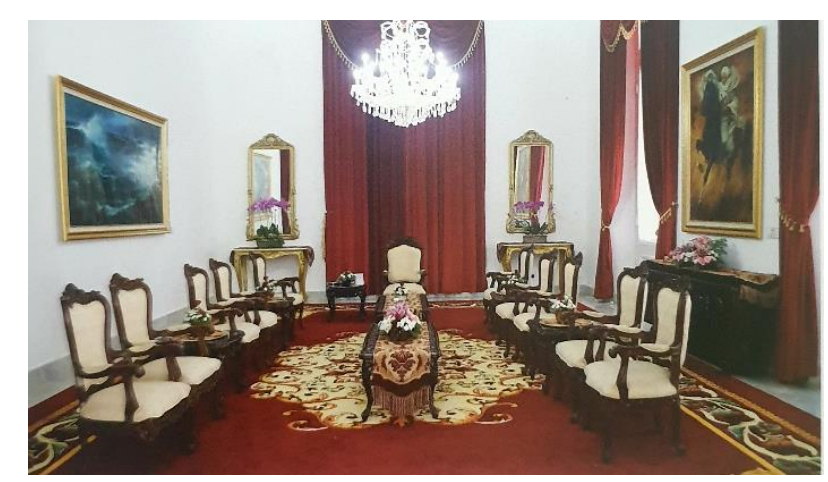

Figure 4. Diponegoro room of Yogyakarta Presidential Palace ( Purnama 2019)

Interior Science, as part of applied art, combines aspects of beauty/aesthetics and the functions, humans strive to give meaning to their life span by making interpretations that are by their beliefs. This belief is in the design (architectural-interior 
context), in the form of thought concepts, which visual language into forms. There are two essential things in architectural-interior works, namely, use and image. Use value refers to profit, the use of pleasure, comfort, and safety. The value of the image comes from more rooted human identities and illuminates the quality of culture. The image between form and design must be precise and convincing, so that quality, image, philosophy become the source of engineering and building expressions. Image is not far from use, but it is more spiritual, it is to one's degree and dignity. Citra refers to the level of culture, while use is more in terms of skills/abilities (Mangunwijaya,1992: 31-32). Space can be felt by humans and can be capture through the five senses in response to its physical (causing the sensitivity of the five senses to affect the existence of space. Psychic space can make a perception in humans to respond to the conditions of the space occupied. Perception is the process of obtaining or receiving information from the environment. Perception is not just sensing; it is to be the interpretation of experience. Interior design must contain precise meanings through the perceptions that expressed.

\section{Art Collection of Yogyakarta Presidential Palace}

The art collection presented as a complement to the Yogyakarta presidential palace layout is an important work that has informative and aesthetic characteristics. The art collection is also one of the historical elements possessed by the presidential Palace of Indonesia and has significant historical value for the Indonesian people and the world. Also, the Yogyakarta presidential palace is a very strategic historical building in Yogyakarta. Learning art and history through space presentation techniques, info charts, and collections is intended to sharpen and elevate a sense of nationalism. Its existence is different from material assets. Where in intangible assets, there are passion, nostalgia, inspiration, creativity, spirituality, and emotions. Cultural heritage is endless to learn because it is the wealth of priceless and irreplaceable for the future, a region/city. In spatial, the interior and art collection axis is in the form of a path that connects the heritage objects physically, symbolizing the journey of culture. The art collection value has a position in the Yogyakarta Presidential Palace with historical objects (physical) as cultural heritage.

Art collection allows visuals to be interested and easy to receive information and competent in responding to things related to visual phenomena by understanding history and art. When President Sukarno was no longer officiate, then these paintings became the heritage of the Indonesian people. There are 17 paintings presented in the museum; some of those are works of Indonesian maestros. These works have the theme of struggle, natural scenery, and Indonesian naturalism. The artist is Raden Saleh - Penangkapan Pangeran Diponegoro (1857) \& Berburu Banteng; S. Soedjojono - Sekko (1947) \& Kawan-Kawan Revolusi (1947); Affandi - Laskar Rakjat Mengatur Siasat (1948); Dullah - Persiapan Gerilya (1947); Kartono Yudhokusumo - Perang di Daerah Pengok (1946); Basoeki Abdullah Perebutan Sinta: Rahwana dan Jatayu (1960), Nasehat Kakek (1960), \& Nyi Roro Kidul (1960); Harijadi Sumadidjaja - Biografi Malioboro II (1950an) \& Anak Tetangga Kita; Sudarso - Potret Seorang Perempuan (1960an); Wiwik Soemiyat Sarinah (1960an); Walter Spies - Kehidupan di Borobudur; Abdullah Surjosubroto Pemandangan Alam; Imant - Laut.

The importance of art collection at Yogyakarta Presidential Palace. The space element must be able to support the function of space so that it is easy to recognize what activities occur in the space. Ordering of these various activities is one way to show the perception of space. A clear spatial structure will help to provide psychological and symbolic support so that it can be a source of emotional/psychological comfort and as a basis for self-actualization. Art learning can be by presenting a collection of art objects in the Yogyakarta Presidential Palace. One example is a painting by Maestro Soedjojono entitled Friends of the Revolution (1947). The purchase of this work 
was at the SIM painting exhibition organized by the Struggle Bureau in Yogyakarta on May 25, 1947. When there were state guests, precisely the Locomotive soccer team from the Soviet Union, Sukarno explained the struggle of Bung Dullah to Bubukin, the group leader. After hearing the story, Bubukin invited all his colleagues to stand in front of the painting and took a moment of silence for Bung Dullah, the humble hero. According to Sudjojono's first wife, Mia Bustam, this painting based on the heroic attitude of a warrior named Bung Dullah (not a Dullah painter). Bung Dullah had succeeded in bombing four tanks of Dutch soldiers with several bombs attached to his waist. Bung Dullah, then, in this painting, among 19 other faces. There is a face of his first child, Tedja Bayu. Then, there are Major Sugiri, Basuki Resobowo, Soerono, Trisno Sumardjo, Ramli, Suromo, Bung Dullah, Nindyo, Kasno, Osman Effendi, Soedibio, Yudhokusumo, and Kartono Yudhokusumo (document from Yogyakarta Presidential Palace).

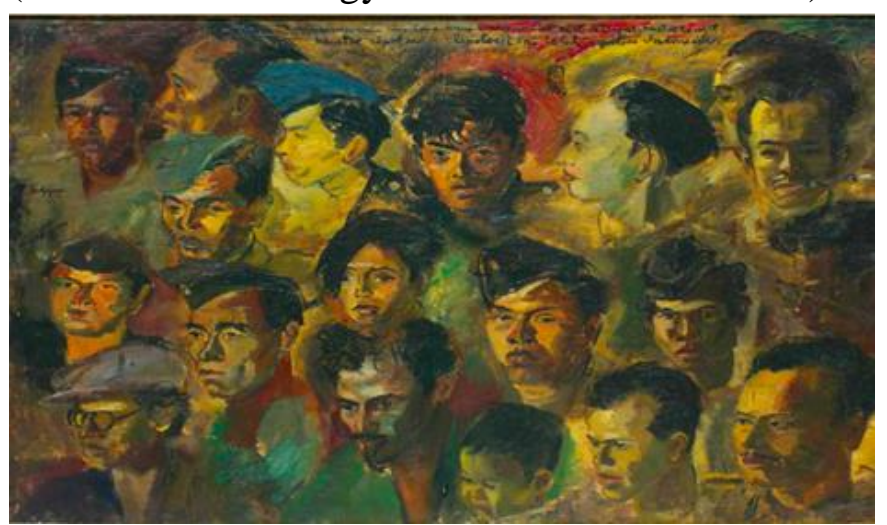

Figure 5. S. Sudjojono's Painting, Friends of the Revolution (Comrade of Revolution) Oil on canvas, 1947, 95cmx149cm (Source: Digital Archive of Contemporary Indonesian Art)

10. The Development of Interior Spaces of The Yogyakarta Presidential Palace

Yogyakarta Presidential Palace has spaces with variety and flexibility over its rooms and has a collection of art objects. Collections that have artistic value are interior elements that can create spaces with more opulent art. The primary purpose of the interior is how to create the atmosphere and function space of a building, which can meet the physical and emotional needs of users. Physically, elements and systems in interior analysis from architecture, including forms (floor plans, visible buildings, etc.), organization of space, circulation, proportions, and so on. Whereas in interior spaces, furnishings and decorations provide optimization of activities and expressions of beauty. The aesthetic position in a design (were), not starting through definitive statements (what). This does not mean there are no aesthetic theories that are not used.

On the contrary, these theories underlie the practice of the aesthetic concept. In the interior design of the Yogyakarta Presidential Palace, several fields of science are interrelated and mutually supportive such as History, Architecture, Graphics, Lighting, and Art governance. Unfortunately, the interior Yogyakarta Presidential Palace still has not obtained a very optimal value as a heritage object that has arts learning on its interior.

The development of interior spaces of the Yogyakarta Presidential Palace aims to improve function, enrich the aesthetic value, and improve the psychological aspects of space. Each design aims to arrange orderly parts into one complete order for specific purposes. Interior Design is one of the fields of scientific study based on design science that aims to be able to create a space along with its supporting elements, both physical and non-physical so that the quality of human life inside is better. The essential elements in interior design are (shapes, textures, lines, spaces, and color) form the basic principles. The interior is a space in a three-dimensional concept having length, width, and height. Space consists of points (where several fields meet), lines (where the two fields intersect), and fields (as boundaries of space) so that shapes are created. The form is the main feature that shows a space determined by the appearance and relationship between fields that explain the boundaries of space. The concept of design in an interior is essential to create a visual hierarchy to assist in emphasizing the space used for the presentation of collections. Interior design is the development of functions, aesthetic enrichment, and enhancement of the psychology of 
interior spaces. Space can be substantial (space has mass), or space (space is inside or limited by planes). These visual characteristics will, in fact, always be influenced by the perspective or perspective of the observer, the distance of the observer to the shape, the lighting conditions, and the visual environment that surrounds the shape (Ching, 1999: 44, 50-52).

A constant form will always include the essential elements of form, the relations or relationships of forms, and the quality of expression. Space is also can express objects, in this case of the Yogyakarta Presidential Palace collection. Form expression is what we see according to influence or previous experience. The spatial expression can be influenced by several aspects, namely the function of space. The function can give birth to an expressive form with a focus. It will appear as a form of space that can support the elements within the space itself. At the same time, Judith Genova and Frederick $A$ in Walker explained the relationship between forms and content, where the relationship between the two is symbolic, which gives connotation and association to something that becomes the reference (Walker, 1989: 155-156). An essential part of the Yogyakarta Presidential Palace is the collection of masterpieces that represent the era from time to time, along with the world of the development of art. In this case, to build the concept of interior layout in the Yogyakarta Presidential Palace can be by giving the right touch of art so that visitors can learn through and with art. The whole approach can by optimizing various aesthetic elements, elements of art objects, and narratives in spatial planning, which are the relations of various aesthetic phenomena and artistic phenomena.

Aesthetic experience is essential because humans are beautiful creatures, are beautiful creatures. Because of the aesthetic experience offered, art education is present that the essence of art education lies in providing aesthetic experience. Efforts to provide aesthetic experience in the interior of the Yogyakarta Presidential Palace by emphasizing the importance that is loaded with historical and artistic significance. To build awareness of people's nationalism, and encourage the development of community education. Yogyakarta Presidential Palace in the future can continue to grow by the development of science and technology.

Interior development consists of interior elements such as innovation, design quality, spatial image, the governance concept of art objects, and the appropriate narrative line. Cultural transformation is responsible for the new concept based on the design strategy. It is a form of visualization (tangible). In cultural communication, the transformation gives appropriate meaning to the interior and symbols as critical cultural values. The space element must be able to support the space function so that it is easy to recognize what activities occur in the space. Ordering these various activities is one way to show the space perception. A clear spatial structure will help to provide psychological and symbolic support so that it can be a source of emotional/psychological comfort and as a basis of self-actualization (Suptandar, 1999).

The concept of presenting maestro paintings at the Yogyakarta Presidential Palace entitled: "Friends of the Revolution" by S.Sudjojono painted on canvas. It uses oil paint and displays no less than 19 faces in various expressions. At the top, it has been written vaguely. "The state of the times took us to one house, one place, one sky, one revolution. This revolution is the Indonesian revolution." From the central point of view, this painting can be one of the main attractions of Paint the Revolution.

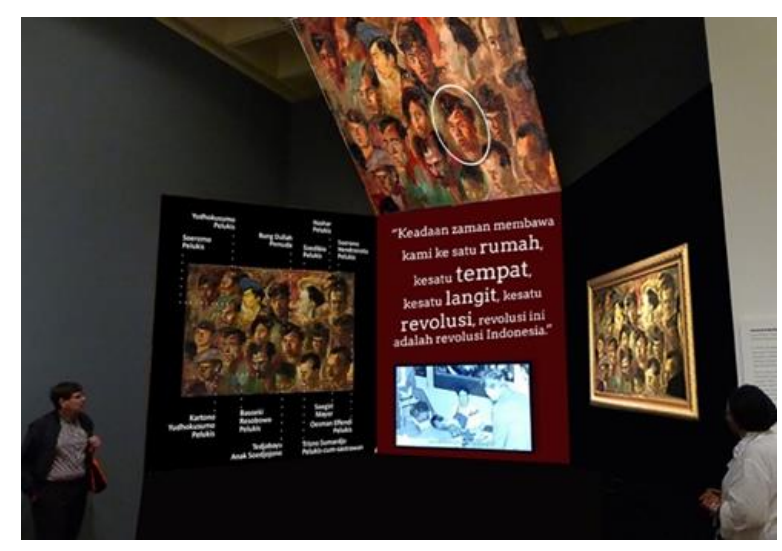


Figure 7. Example of the art learning through painting presentation concept in the interior of the Yogyakarta Presidential Palace. (Ika Yuni

Purnama compiled them)

The richness of Indonesian art and culture in the Yogyakarta Presidential Palace is a tool to introduce the culture and character of the Indonesian people. Cultural aspects presented in the collection of Palace art objects are a vehicle for cultural diplomacy. By visiting the Palace, it looks like that guests from abroad, who watch dance treats, dining table dishes, carvings, paintings, and sculptures filling the corner of the Palace, are visiting all over Indonesia. Opening cultural space in the Yogyakarta Presidential Palace is one way to make the Palace more inclusive and friendly to the community.

The interior is creating space through the process of organizing, filing, completing, and strengthening the functional arrangement and the realization of the image, sense, ambiance, space theme, by the characteristics of space users, motion and activities that occur in space. The primary purpose of the interior is how to create the atmosphere and function space of a building, which can meet the physical and emotional needs of users. Physically, elements and systems in the internal analysis are inseparable from architecture, including forms (floor plans, building views, etc.), money organizations, circulation, proportions, and so on. Whereas in interior spaces, furnishings and decorations provide optimization of activities and expressions of beauty.

Aesthetic for interior space includes the beauty of form and expression. The beauty of form is the real beauty. It has a specific size that applies to all kinds of beauty. It means that the conditions of cohesiveness, balance, proportion, and scale. On the other hand, the beauty of expression is about something more abstract, which is more difficult to measure or count because it is to character, style, and color. Communication is an essential thing in human life because communication can occur in every human's motion and space, as well as its environment. In the field of interior design, to implement this definition, communication as the activity of using symbols that can be together by parties involved in communication activities. In interior design, the communication process occurs with the use of symbols from space-forming elements and space-filling elements. Interior spaces can be a means of communication in learning art for visitors by using various methods in spatial planning and space themes. It includes using communication technology, building local and national support networks, education, and cultural communication. Form of communicationrelated to the governance of collection objects is by displaying narration on each collection of objects and narrative lines to form the space theme through the presentation of words, sentences, numbers, and symbols/images. Graphics used to attract attention, clarify the idea of presentation, and illustrate facts so that they are exciting and memorable. The function of visual media is to attract attention, clarify the presentation of the lesson, and illustrate a fact or concept that forgotten if only done through a verbal explanation. The graphic media functions to channel messages from the source to the recipient. The channel used involves the sense of sight. The message is visual communication symbols.

\section{Conclusion}

Based on this argument, the interior space and objects of the Yogyakarta Presidential Palace art collection are a collaboration of aesthetic values related to ideas (designs), actions (activities), and works of art (objects of art collections), as supported by theories proposed by theories previous. Interior space in Yogyakarta Presidential Palace as part of applied art combines aspects of beauty/aesthetics, and the humans strive to give meaning to their life span by making interpretations that are by their beliefs. This belief is in the design (interior context), in the form of thought concepts, which visual language into forms. The purpose of interior design is a functional improvement, aesthetic enrichment, and psychological 
improvement. The aesthetic value in interior space Yogyakarta Presidential Palace can reconstruct the past for the present by applying the collection of art objects that have artistic value as an added value to the atmosphere of the space, and the narrative line (storyline) in the design concept. The development carried out in applying the interior model by presenting a collection of historical paintings is the learning of art through narration, which is by visual media to increase the ability of visitors to appreciate.

The new concept is to improve function, to enrich the aesthetic value, and to enhance the psychological aspects of space. The art collection in interior spaces becomes an important part and can be appreciated by visitors. With infographic technology, the interior and art collection of Yogyakarta Presidential Palace become an aesthetic phenomenon that gives its value in the development of the interior design. The elements that make up the room of the Yogyakarta Presidential Palace and the collection of art objects therein support the collection of art objects form and meaning or content as communication from the informational narrative in the space and the presentation of art objects. The interior and art collection values optimized as cultural heritage assets. Provide narration in interior spaces in the Yogyakarta Presidential Palace is a useful and readily appreciated tool for visitors.

\section{Acknowledgment}

The authors wish to thank Semarang State University and Jakarta Institute of the Arts for all support. Many thanks to all the managers of the Yogyakarta Presidential Palace who provided valuable information for this research

\section{References}

[1] Annam, K. (2019). Pengelolaan Lukisanlukisan Koleksi Museum Istana Kepresidenan Yogyakarta. ARS: Jurnal Seni Rupa dan Desain, Vol.22, No 3.

[2] Ching, D.K., Francis. (2002). Architectue, Space and Order. New York, New York: Maxmillan Publishing Company.
[3] Mangunwijaya, JB. (1992). Wastu Citra. Jakarta: Gramedia Pustaka Utama.

[4] Moleong,Lexy. J. (2006). Metodologi Penelitian Kualitatif. Bandung:Remaja Rosdakarya.

[5] Susanto,M, GR. Lono L. Simatupang, Timbul Haryono. (2018). Curating the Painting Collection of the Presidential Palace of the Republic of Indonesia. Jurnal Lekesan: Interdisciplinary Journal of Asia Pasific Arts (Volume 1, Issue 1, April 2018 p19-29).

[6] Suptandar, J. Pamudji. (1999). Desain Interior .Jakarta: Penerbit Djambatan.

[7] Walker, John A. (1989). Design History and the History of Design.London: Pluto Press, London.

[8] Wadjiz A. Filsafat Estetika. (1980)'s[epididagdo. Pluralisme Dalam Estetika. Orasi Ilmiah pada Sidang Terbuka Senat ITB. Penerbit Nur Cahya.

[9] Widagdo. (2006). Estetika Dalam Perjalanan Sejarah : Arti dan Perannya Dalam Desain. Jurnal Ilmu dan Desain. Bandung: Fakultas Seni Rupa dan Desain ITB, Vol.1 (No.1).

[10] Yuke Ardhiati. (2017). " A New Museum of Indonesian Batik: An Architecture of "Showing off". ISSN 1934-7367 (online). ISSN 1934-7359(print). Jurnal of Civil Enginering and Architecture. Volume 11, Number 3, March 2017 (Serial Number 112). 